\title{
DISSIDENT COMMUNICATIONS: NON-PERIODIC UKRAINIAN SAMIZDAT (1960-1987)
}

\section{Spanatiy O. S.}

\section{INTRODUCTION}

From the time of the appearance of Ukrainian samizdat (self-printed or self-published texts) and until 1987, many different works and documents were prepared and distributed (we recorded 618 titles) they were distributed in Ukraine and abroad, some documents reached numerous circulations. This significant amount of printed information is not streamlined and systematized, because so far the researchers have not considered the documents of the Ukrainian samizdat as a separate type of unofficial publishing products.

O. Obertas in his monograph "Ukrainian samizdat: literary criticism and journalism (1960s - early 1970s)" systematizes the documents of Ukrainian samizdat by subject. He singles out documents aimed at protecting the Ukrainian language and culture, the struggle for civil liberties and rights, documents devoted to the national question and national policy of the USSR, information and protest documents, and "professional" literary-critical documents ${ }^{1}$.

In the first issue of "Ukrainian Herald", V. Chornovil systematized selfpublished texts on a chronological and thematic basis and singled out literary documents (until 1963), anonymous articles on social and national problems (1963-1965), articles with author's signatures, in which the problems of public life were analyzed from the Marxist-Leninist platform ${ }^{2}$. G. Kasyanov took the same periodization as a basis in his research ${ }^{3}$.

Given these facts, we set the goal to examine the documents of Ukrainian samizdat using the typological method from the perspective of publishing, to highlight the characteristics and to classify the documents of Ukrainian samizdat based on them.

1 Обертас О. Український самвидав: літературна критика та публіцистика (1960-ті - початок 1970-х років). К. : Смолоскип, 2010. 300 с.

2 Чорновіл В. Твори: у 10 т. К. : Смолоскип, 2006. Т. 3: Український вісник. Випуски I-VI. С. 153.

${ }_{3}^{3}$ Касьянов Г. Незгодні: українська інтелігенція в Русі Опору 1960-1980-х років. К. : Либідь, 1995. С. 89. 


\section{Typological characteristics of texts of non-periodic Ukrainian samizdat (1960-1987)}

After analyzing the materials of Ukrainian samizdat, which were distributed from 1960 to 1987 for their intended (functional) purpose, we found that there are more names of socio-political documents. Their share of the total number of analyzed documents is $87.22 \%$. The following positions are occupied by literary and artistic works $-6.63 \%$, official $-4,21 \%$, reference $-1,29 \%$, scientific $-0,65 \%$.

A significant amount of socio-political material can be explained by the high demand in society for information of this type and the inability to satisfy it with official print media. The documents described resonant events, were hushed up by the authorities, for example, in the article "Regarding the trial of Pogruzhalsky", Ye. Sverstyuk reported the arson on May 24, 1964 of the Kiev Public Library of the Academy of Sciences of the Ukrainian SSR, the document "Repressions in Dnepropetrovsk" spoke about repressions by the authorities. Public speeches were distributed: "Speech at the funeral of Alla Gorsky" by I. Gelya, "Speech at the evening dedicated to the 30th birthday of Vasily Simonenko" by I. Dziuba, "Last word on the court" by V. Chernovol and others. Regarding the future of Ukraine and the USSR began a political discussion on the pages of Ukrainian samizdat, for example: "Communist Thoughts on the Present and Future of the Ukrainian People" by Ye. Pronyuk, "Modern Imperialism", "Economic Monologues" by M. Rudenko.

The number of titles of socio-political documents has been increasing since 1963 (8 titles), in $1964-12$ titles, and in $1965-28$ titles. In the future, each year the number of such documents appears at the same level, with the exception of 1970, when 66 socio-political documents were recorded, 1977 - 51 names, 1979 - 53 names. Since 1981, interest in documents of this direction as well as in samizdat has been declining, only 15 names have been recorded. In the following years, this trend continued, and in 1987 we recorded only four names. On average, from 1960 to 1987, 20 titles of sociopolitical documents appeared each year.

Socio-political documents are divided into nine types on the basis of information: articles, letters, statements, petitions, complaints, explanatory notes, public speeches, diaries, protests. Briefly describe each of these types of documents.

Letters. By the number of names we recorded letters - 203 names, $39,11 \%$ of the total. We discovered the first letter distributed by the Ukrainian samizdat in 1963, and their number increased over the years. In 1964, two similar documents were already recorded: the first was entitled "I share your indignation..." (correspondence of V. Lobko and M. Rylsky) 
and "Appeal of a group of believers to the World Council of Churches", in 1965 seven names were recorded. The maximum number (27) is registered in 1977. After 1980 (ten titles), the number of letters decreases to one or two per year. The popularity of this type of document is explained by the simplicity of its creation and its legality in case of sending to any authority.

It was more difficult for the KGB to prove that the document was antiSoviet if it was sent to an official state institution. This also applied to other documents that were distributed. On average, 7.5 letters appeared annually.

Articles. For this period we identified 148 articles, which is $28,51 \%$ of the total number of non-periodic socio-political documents. The first article was recorded in 1961, the number of such documents gradually increased, 25 article titles were fixed in 1970. Later, articles appeared irregularly in Ukrainian samizdat. 13 articles were recorded in 1975 and 12 articles were recorded in 1979.

Since 1981, the number of names has been sharply reduced to one or two per year. The articles covered historical events, for example: "From the history of the struggle of the Ukrainian people for their liberation during the Civil War" by M. Masyutko, anonymous article "Lessons of History". The political polemic was especially active in 1965: "On a Political Mistake" by S. Karavansky, "Class and National Struggles at the Present Stage of Human Development", "Nationalists?" and etc.

In 1966, I. Svitlychny arranged documents related to the trial of members of "The Ukrainian Workers and Peasants Union" (L. Lukyanenko, I. Kandyba, S. Virun, etc.) entitled "To the case of Levko Lukyanenko and others". With his introduction, these documents were sent to party, Soviet, law organizations, and illegally were sent abroad, where they were published in a separate brochure entitled "Ukrainian Lawyers under the KGB Court"".

After repressions against dissidents increased, lawsuits and prosecutions are described in the articles: "Arrests and Trials in Kharkov" (1970), "Svyatoslav Karavansky Process" (1970), "Another Massacre of V. Moroz is being Prepared" (1970) and etc. In 1979, all articles were devoted to repressed persons, for example: "Before the arrest of Mykola Horbal" by M. Landa, "On the fate of Vasyl Dolishny", "The Process of Vasyl Ovsienko" and others. In total, 5,5 articles appeared annually during the study period.

Statements. According to our data, there were 93 such documents, which is $17,92 \%$ of the total number of non-periodic socio-political texts. The first statement is dated 1965. In it, V. Lutskiv addressed the Central Committee of the Communist Party of Ukraine. The author said that he was intimidated

\footnotetext{
${ }^{4}$ Українські юристи під судом КГБ. Мюнхен : Сучасність, 1969. 107 с.
} 
and forced to sign fabricated protocols. Since 1967, statements have been steadily distributed by Ukrainian samizdat, although their number was not constant. Most applications were recorded 1979 (17 names), for example: I. Sokulsky's statement "For the right to be a Ukrainian", V. Chornovil's "Application for admission to the UGG", V. Stus's "Application to the Prosecutor of the USSR in defense of Mykola Horbal" and others. Since 1980, the number of applications has been reduced and does not exceed one names per year. On average, 3,4 statements were distributed annually by Ukrainian samizdat.

Public performance. These socio-political documents account for 5\% of the total, 26 titles are recorded. This type of Ukrainian samizdat documents has been distributed since 1963. It was then that the paper versions of the speeches of I. Svitlychny and Ye. Sverstyuk at the evening in memory of V Symonenko at the Kyiv Medical Institute were published for the first time. For another ten years, until 1973, public speeches were systematically distributed by the Ukrainian samizdat for two or three titles a year, but from 1974 to 1987 only four such documents were recorded. In the beginning of the 60s speeches on literary topics were mainly distributed, then after 1965 there were "last speeches" in court: The court statement and the last word on the court in Lviv" by M. Gorynya (1965), "The last word on the court in Lviv" by V. Chornovil (1967), "Instead of the Last Word" by V. Moroz (1970) and others. On average, one public appearance was distributed each year.

Complaints. During the study period, we recorded 20 complaints, which is $3,85 \%$ of the total number of socio-political documents. These documents appeared in the Ukrainian samizdat in 1965. This year, A. Horska's "Complaint to the Prosecutor of the USSR" and 17 mothers' collective "Complaint to the Ministry of Education" were distributed. Complaints were circulated regularly from 1965 to 1981, but were no longer recorded. Most of them were related to lawsuits against Ukrainian dissidents and were aimed at protecting the authors, for example: "A Complaint to the Prosecutor General of the USSR about the illegality of the trial against him and six others" by L. Lukyanenko (1967 ), "Cassation appeal to the Supreme Court of the Yakut USSR" by V. Chornovil (1980), "Complaint to the Supreme Court of the USSR" (1981) by S. Sichko and others. On average, 0,4 complaints appeared each year during this period.

Petitions. They occupy a small part of the socio-political documents of Ukrainian samizdat, only 2,2\%, 11 titles. Such documents were distributed only for a short time from 1964 to 1970. Probably, this situation has developed due to the specificity of this type of documents and the narrow scope of their application. But some documents were quite popular and 
widely distributed, for example: "Petition to the Prosecutor of the USSR about serious mistakes and the proclamation of Russification by the Minister of Higher and Secondary Education of the USSR Yu. M. Dadenkov" by S. Karavansky. On average, 0,4 petitions were appeared in the Ukrainian samizdat each year.

12 titles of protests were recorded, which is $2,31 \%$. Two protests date back to 1967: "Protest of 64 citizens by LI Brezhnev, P. Yu. Shelest and I. Kh. Golovchenko against the actions of the police on June 22, 1967 - the day of the annual commemoration of Taras Shevchenko" and "Protest to the head of camp 17-A, Lieutenant Kishka". Such documents appeared irregularly, the next two protests were recorded in 1970. In general, almost all protests are dedicated to the protection of dissidents from various actions by the authorities. On average, 0,4 protest names appeared each year.

Diaries are one of the few types of socio-political documents, which is only $0,58 \%$ or three titles. Such documents did not appear regularly. V. Symonenko's Diary was the first in the Ukrainian samizdat, the author shared his thoughts about the state of Ukraine, the Ukrainian language and criticized Soviet bureaucrats. This document was distributed by I. Svitlichny. In 1976, M. Rudenko's diary was distributed under the title "Case history (diary of a candidate for schizophrenics)" and in 1979, G. Snegirev's "Diary" was distributed.

Explanatory notes. These are the least common documents: we have recorded only three names, which is $0,58 \%$. The first explanatory note dates from 1963. In it, I. Dziuba expressed his indignation at the authorities' attempts to ban the evening in memory of Lesya Ukrainka, and also explained why this evening took place in the Central Park of Culture and Recreation in Kyiv on July 31, 1963. Later, in 1965, M. Masyutko's "Explanations to the Prosecutor of the Ukrainian SSR" were distributed, and in 1979, V. Striltsiv's "Explanations to the Director of the Dolyna Plant of Reinforced Concrete Products and Structures" were distributed.

According to contemporaries, in the early 1960s literary works were quite popular. But we recorded only 41 names, $6,63 \%$ of the total. Such documents appeared regularly every year

Most of all literary works were recorded in 1965 (nine titles), including literary articles "Literature and pseudo-literature in Ukraine" by M. Masyutko, "Taras Shevchenko as assessed by Boris Grinchenko" by V. Chornovil, "A cleansing and life-giving raven: motives of national shame and national self-criticism in Shevchenko's poetry" by I. Dziuba and a collection of poems by V. Stus, I. Kalynets. A small number of titles of literary works is explained by the absence of a ban on literary activities by the authorities, by the reorientation of Ukrainian samizdat to other types of 
documents, in particular socio-political. On average, two titles of literary works appeared each year during this period.

According to the information feature, literary works are divided into articles (13 titles) and literary works (28 titles), which is 32\% and 68\%, respectively. Literary articles were distributed only until the mass repressions against participants in Ukrainian samizdat in 1972. These are literary articles by I. Dziuba, Ye. Sverstiuk, V. Chornovil, M. Masyutko and others, that were not officially published due to administrative pressure on the authors. Most literary works are collections of poems, for example: "The Twirl" by V. Stus, "Summing up the silence" by I. Kalynets, "Slave's cries" by Z. Krasivsky etc. This type of documents of the Ukrainian samizdat also includes the autobiographical novel "The Thorn" by M. Osadchy and the novel "Cathedral" by O. Gonchar.

We have recorded 26 official documents, which is $4,21 \%$ of the total number of documents. The first official document has been circulating since 1960. It was a "Certificate of release from prison after 15 of the 25 years sentenced for treason" by S. Karavansky. Later, such texts appeared irregularly in the Ukrainian samizdat until 1969. Since 1966, after the completion of the first trials of Ukrainian dissidents, more official documents have appeared in the samizdat, court verdicts have been distributed: "Verdict of the Kyiv Court in the case of Yaroslav Gevrych", "Verdict of the Lviv Court in the case of Ivan Gel and Yaroslava Menkush" etc.

On the basis of information, we distinguish the following types of official documents: court verdicts, letters, certificates, articles. Judgments are the main part of official documents $(65 \%, 17$ titles), letters - 27\%, 7 titles, the certificate is recorded only one $-4 \%$ and one article $-4 \%$. Official letters include documents prepared by the Ukrainian Helsinki Group, for example: "Memoranda", "Appeal of the Ukrainian Helsinki Group" (1977) etc.

Only $1,29 \%$ of the total number ( 8 titles) of reference documents were recorded. The first document was recorded in 1966. This is "The List of 58 Ukrainians administratively persecuted for their beliefs". This small anonymous leaflet provided information about the administrative persecution of Ukrainians.

Next year, V. Chernovol prepared the most famous reference document: "Woe from Wit, or Portraits of 20 "criminals", which "Radio Liberty" in " the Collection of samizdat documents" called an encyclopedia 5 . All reference documents of that period informed about the repressions against Ukrainians.

\footnotetext{
${ }^{5}$ Музей-архів українського самвидаву “Смолоскип”, п. № 18.
} 
Among the texts of the Ukrainian samizdat, we recorded only four scientific examples $-0,65 \%$ of the total. "Internationalism or Russification?" by I. Dziuba in 1965 and "Speech by Vasyl Lobko at the All-Ukrainian Republican Scientific Conference on the Culture of the Ukrainian Language on February 12, 1963" were the first to spread. The next year, M. Baichevsky's article "Accession or Reunification" was published, and in 1969 K. Kozub's article “On B. Antonenko-Davidovich's Article “A Letter to Be Longed For" was distributed.

We divide documents of non-periodic samizdat by material construction into sheets, photocopies, copies of the "Era" and linotype prints. Sheet documents are documents printed on a regular typewriter, on A4 sheets, regardless of the number of copies loaded in the typewriter and of the paper's quality. Most of the documents of the Ukrainian samizdat were created and distributed in this form. Among all the documents recorded by us, $99 \%$ of titles (612 units) can be included in the sheets.

Ye. Sverstyuk described the process of creating and reproducing sheet documents: "I remember how Ivan Svetlichny came to me with records of Danylo Shumuk's memoirs and asked to find a typist, because he needed copies. By the way, I somehow managed to find typists, brave typists, and in different places. For example, one of them worked in the Central Committee of the Communist Party. However, the typist also wants to make money in the Central Committee, and she had more paper of good quality. Later this typist was so brave that she began to reprint "Internationalism or Russification?" by Ivan Dzyuba ${ }^{6}$.

Among the self-published documents, only $1 \%$ of the titles can be attributed to photocopies (six units). However, this does not mean that photocopies were uncommon at the time. Films with re-photographed documents took up little space, were easy to hide, and the information stored on them was easily reproduced even at home, of course, with the necessary technical means.

I. Dziuba recalls the process of making photocopies: "We had a small illegal workshop where photocopies of samizdat materials were made. By the way, Kabalyuk brothers and Hryhoriy Tymenko did this, Tymenko had already disappeared without a trace by that time. My work and Chornovil's book were copied there. The KGB really wanted to get to this workshop ... In the end, they didn't find this workshop",

${ }^{6}$ Бердиховська Б., Гнатюк О. Бунт покоління: Розмови з укр. інтелектуалами. К. : Дух і літера, 2004. С. 67.

7 Ibid., c. 143. 
According to the Virtual Museum of the Dissident Movement, J. Gevrych personally made photocopies of documents, the disabled artist P. Morgun (he had one hand) helped him for some time. Photocopies of the samizdat were made from the film that J. Gevrych received from Ye. Pronyuk ${ }^{8}$. An example of the distribution of photocopies of documents is in L. Svitlychna's memoirs: "A photocopy of A. Avtorkhanov's book "Technology of Power" appeared in Kyiv. There was a queue to read it. When Ivan's turn came and a photocopy of the book appeared in our apartment, everyone started reading on the conveyor belt, passing the pages to each other - Ivan, his cousin, also Ivan Svitlychny, and I. The second part was in Nadia..."

Often it was not sheet documents that were sent abroad, but their photocopies. Thus, on May 26, 1966, at a scientific conference in Uzhhorod, G. Avrahov approached Yuri Bach and offered to read an interesting book in the form of a pack of photocopies. Since there was no time to read it, Yu. Bach asked to take it with him (he had no idea about the content of the book) and only at home he realized that it was "Internationalism or Russification?" by I. Dziuba ${ }^{10}$.

In the 1960s, "Era" Soviet copy machines were often used. Such machines were located in large institutes or government agencies, and although their work was strictly monitored, they were often used to replicate samizdat. The verdict of the Judicial Board for Criminal Cases of the Supreme Court of the Ukrainian SSR in the case of Yu. Prober may be evidence of such use. On March 17, 1970, he was found guilty of "working as an operator of an electrographic reproduction apparatus at the Promstroyproekt Institute, and then at the Ukrdniprotsukor Institute, taking advantage of the uncontrollability of the management of the institutes, Yu. Prober systematically produced and distributed printed works defaming the Soviet state and social system" ". The court verdict states that Prober personally produced and distributed anti-Soviet literature on the Era apparatus: "Pamphlet Reflections on Progress, Peaceful Coexistence and Intellectual Freedom" by Sakharov, "An Open Letter to Stalin”, “An Open Letter to M. Sholokhov, author of The Quiet Don" by F. F. Raskolnikov,

8 Геврич Ярослав Музей дисидентського руху. URL: http://archive.khpg.org/ index.php?id=1257671444.

9 Доброокий: Спогади про Івана Світличного. Упоряд. Леонід і Надія Світлична. К. : ЧАС, 1998. С. 35.

${ }^{10}$ Спанатій О. С. Канали перевезення самвидаву на Захід у 1960-1980-х рр. Наукові записки Інституту журналістики: науковий збірник. К., 2009. Т. 35. Квітень-червень. С. 40-42.

${ }^{11}$ ЦДАВО України. Ф. 24, оп.: 16, од. зб.: 1113, спр. № 05-205. Арк 70. 
“Open Writers' Party Meeting, Moscow 1965” by G. Ts. Svirsky, "European Pop" by B. Slutsky, "Notes on the Autobiography", "A Short Record of the Meeting of the Great History Department World War II Institute of Marxism-Leninism under the Central Committee of the CPSU of February 16, 1966", "Letter to I. G. Erenburg", "Speech at the seminar "Personality in the Twentieth Century" by Ye. Yevtushenko and other literature. In total, 2,084 copies and 603 titles of various documents were confiscated from $\mathrm{Yu}$. Prober. Documents were prepared for sale, and this indicates a high demand in society for samizdat and other information prohibited for distribution in the USSR ${ }^{12}$.

There is also evidence of the production of samizdat documents using a self-made glass graph. The verdict of the Judicial Board for Criminal Cases of the Supreme Court of the Ukrainian SSR of September 21, 1967 states in the case of V. Kyrylko that he lived in Kyiv and was an active member of the community of Evangelical Christian Baptists from 1966 to 1967, had typewriter and self-made duplicator - glass graph, chemicals and other means of printing, produced illegal literature, which was distributed in Kiev, Kiev region and other cities of the USSR. The investigation established that 1,120 copies of the magazine "Brotherly Leaflet" and "Appeal" were sent to Lviv, Rivne, Volyn, Chernihiv, Fastov, Bila Tserkva, Vinnitsia, Zhytomyr, Homel and other areas. During a search of V. Kirilko's apartment, 35 magazines "Bulletin of Salvation", 38 magazines "List of Prisoners" were confiscated $^{13}$.

Documents of the Ukrainian non-periodical samizdat are grouped by volume in accordance with the current standard DSTU 3017-95 ${ }^{14}$. Of the documents we registered, it was not possible to establish the volume of 72 documents, which is $11,65 \%$ of the total. Postcards contain more than half of the samizdat texts, 331 titles $(53,56 \%)$ have been registered. Brochures were registered a smaller share $(29,13 \%$ of the total -180 titles). The least number of books was registered ( 35 titles or 5,66\% of the total).

Postcards were distributed in Ukrainian samizdat only in 1964, we registered eight names. Later, the number of such documents increased until 1970 (37 titles were registered), during the years of mass repression (1971-1973) the number of postcards decreased to six per year, but since 1974 their number has increased again. The maximum number of postcards was recorded in 1977. There were 44 titles. The prevalence of four-page

${ }^{12}$ ЦДАВО України. Ф. 24, оп.: 16, од. зб.: 1113, спр. № 05-205. Арк 70.

${ }^{13}$ Ibid., арк 67.

14 ДСТУ 3017-95. Видання. Основні види. Терміни та визначення. К. : Держстандарт України, 1995. 47 с. 
documents in the Ukrainian samizdat can be explained by the ease and speed of production and reproduction. The prevalence of four-page documents in the Ukrainian samizdat can be explained by the ease and speed of production and reproduction. Large documents required more time for reprinting or photocopying and big material costs. The postcards were actively distributed until 1980, after which their number began to decline sharply.

Due to their small volume, the brochures were also widely distributed in the Ukrainian samizdat, and their distribution began a little earlier than postcards' and books' distribution. In 1967 and 1970, 17 titles of brochures were recorded, and in 1979 their number reached 19 titles. The decrease in the number of brochures in the Ukrainian samizdat has been recorded since 1980. Ukrainian books appeared in the samizdat in 1963 and were regularly distributed until 1980 in the amount of two titles per year.

According to the composition of the main text, monodocuments are the majority of recorded documents $-93,68 \%$ of the total number (579 titles), collections are only $6,32 \%$ (39 titles). This advantage of monodocuments is explained by the fact that each author distributed works separately from others, without enclosing them in collections but without combining articles by other authors. Monodocuments have been distributed by the Ukrainian samizdat since 1960, their number gradually increased and in 1970 reached 71 titles. The collections have been distributed since 1963, and we were the first to record "Documents on the events in the Holy Dormition Pochayiv Lavra". Collections were distributed more or less regularly until 1980, on average, 1,6 titles per year. Most of the recorded collections are poetry collections by I. Kalynets, V. Stus, V. Holoborodko, Z. Krasivsky, M. Kholodny, L. Kostenko and others.

The picture of the periodicity of Ukrainian samizdat documents looks interesting. Most of them are non-periodicals. They accounted for $98,06 \%$ of the total (606 titles). Only 1,94\% of documents (12 documents, five titles) were recorded as serial documents. Serial documents are divided into periodic and continuing. Periodic documents include documents issued with a certain periodicity (once a quarter, month, week, daily, etc.) with increasing numbering, with unique information material, under one name, in the same type of design ${ }^{15}$. Only two recorded documents can be attributed to this type: "The Noise of Perestroika" (1987) and "Chronicle of the Catholic Church in Ukraine" (1987).

Continuing documents are published without clearly defined preintervals, as the accumulation and editorial preparation of materials, they

15 Тимошик М.С. Книга для автора, редактора, видавця : практ. посіб. 2 вид., стер. К. : Наша культура і наука, 2006. С. 96. 
have own numbering and typical artistic and technical design ${ }^{16}$. Only three titles of documents belong to the continuing ones: "Will and Motherland" (1964), "Ukrainian Herald" (1970) and "Information Bulletin of the Ukrainian Public Group" (1980).

Serial documents are divided into newspapers, magazines and bulletins on the basis of information. The concept of "newspaper" includes the publication "The Noise of Perestroika", magazines "Volya i Bat'kivshchyna", "Ukrainian Herald", "Chronicle of the Catholic Church in Ukraine", and the bulletin "Information bulletin of the Ukrainian public group". Serial documents were distributed by Ukrainian samizdat irregularly and always by the efforts of a small group of people in conditions of conspiracy. However, KGB officers were particularly meticulous in their attempts to create unauthorized texts in Ukraine, so the arrest of the organizer was only a matter of time. Obviously, there have been so few attempts to establish such publications because of this factor. We observe this picture until 1987, when after Gorbachev's proclamation, the KGB stopped persecuting the citizens of their country for illegal publishing activities, and since that year a large number of unofficial periodicals have been published ${ }^{17}$.

There are two groups of self-published texts, divided by the originality of the content. It should be noted that the original language of writing documents in Ukraine was both Ukrainian and Russian, although the documents were not written on Russian very often. However, in Ukraine, in parallel with the Ukrainian, the documents of the Russian samizdat and other republics were distributed, so it is difficult to say unequivocally which language prevailed in the uncensored circulation. Most of the recorded documents are original (94,98\% (587 titles)) and only 5,02\% (31 titles) are considered translated.

There are four types of documents according to the author: anonymous, departmental, own and collective. By analogy with the current standard, we call our "own" documents those that were prepared by one author and distributed under his signature. This group includes most of the documents $69,74 \%$ (431 titles). The second largest number is the type of anonymous documents $-16,02 \%$ (99 names), collective documents are recorded slightly less $-11,33 \%$ (70 names), and only 2,91\% (18 names) are departmental documents.

16 Тимошик М.С. Книга для автора, редактора, видавця : практ. посіб. 2 вид., стер. К. : Наша культура і наука, 2006. С. 96.

17 Кіпіані В. Самвидав як проба протистояти цензурі // Дивен Світ. URL: http://dyvensvit.org/suspilstvo/178-suspilstvo-statti/3111-vahtang-kipiani-samvydav-jaksproba-protystojaty-cenzuri. 
In the first issue of "Ukrainian Herald" V. Chornovil notes that anonymous articles, which touched on acute social and national problems were distributed from 1963 to 1965. According to V. Chornovil, these articles caused the arrests in $1965^{18}$. Anonymous documents really began to be distributed since 1963, but their number gradually increased until 1970, in which 19 names were recorded. Then, the number of anonymous documents continues to decline, although they appear fairly regularly until 1981. Anonymous documents include "Ukrainian Herald", among other things, in the first issue of which, it was declared that "in its content and purpose it (the publication) is completely legal and constitutional" and explained that "we have frequent violations of constitutional guarantees and unlawful persecution of socially active people" 19 . Short reports of certain events were often anonymous: "Returned from Prison" (1970), "Trial in Dnipropetrovsk" (1970), "Arrests and Courts in Kharkiv" (1970) and others.

The distribution of collective documents has been recorded since 1964 and continues until 1971. After a two-year hiatus related to repression, collective documents continued to be distributed by Ukrainian samizdat until 1981. The vast majority of collective documents are aimed at protecting civil rights and freedoms in general or a specific person. The most famous collective document is considered "Letter 139" sign by more than 150 people. The letter expressed protest against political processes against young people from among creative youth and scientific intelligentsia and against a violation of the principle of publicity. Immediately after the letter, "Ukrainian Herald" submitted a list of those who had been punished for signing $i^{20}$. Obviously, due to the repressive actions of the authorities and the low efficiency of collective appeals and documents, they were not widely used in Ukrainian samizdat.

The least common type of affiliation to the author are departmental documents. These include those that have been prepared by government agencies. Such documents have been distributed by Ukrainian samizdat not regularly since 1960. More departmental documents were recorded in $1970-$ four names, such documents were distributed until 1983. On the basis of information, the majority of departmental documents comprise court sentences, of the 18 recorded documents, 15 are court verdicts. "Verdict of the Kyiv Court in the case of Yaroslav Hevrych" (1966), "Verdict of the Lviv Court in the case of Ivan Hely and Yaroslav Menkush" (1966),

18 Чорновіл В. Твори: у 10 т. К. : Смолоскип, 2006. Т. 3: Український вісник. Випуски I-VI. C. 153.

${ }^{19}$ Ibid., c. 61 .

${ }^{20}$ Ibid., c. 129. 
"Decision of the Supreme Court of the Ukrainian SSR in the case of Valentin Moroz" (1970) and others were spread. Distribution of certificates, summonses, documents on criminal cases, etc. was also recorded.

The study analyzed the documents of the Ukrainian samizdat on the basis of language. In total, we recorded 460 documents written in Ukrainian, which is $74 \%$ of the total. 158 documents are written in Russian, which is $26 \%$ recorded. It is worth noting that some of these documents in the original were written in Ukrainian, however, Russian translations came into our view and vice versa.

\section{Thematic characteristics of the texts of the Ukrainian non-periodical samizdat (1960-1987)}

To facilitate the work with the documents of the Ukrainian samizdat and optimize the search for the necessary information, they should be classified by topic. Today, both researchers and publishers and readers use different systems to classify any publishing product: publishers use the Library Bibliographic Classification (BBC), and modern bookstores use the Unified Classification System for Literature for Publishing (ECCL). The Book Chamber of Ukraine uses the "Universal Decimal Classification" (UDC). The latter classification is characterized by in-depth detail of the main tables and has significant opportunities for the introduction of new headings using determinants, thus being considered one of the most developed universal classifications $^{21}$. Documents can be classified according to any of the systems, but in none of them the texts of samizdat are singled out as a separate thematic group. Their identification is possible only on general principles. In our opinion, this approach will only confuse and complicate the work with documents.

Taking into account the specifics of samizdat documents, we single out the most important topics of Ukrainian samizdat and on their basis classify various documents. Most documents directly or indirectly relate to human rights issues, as the very fact of the existence of samizdat testifies to the struggle in society for the right of citizens to disseminate and receive any information. To this topic are added several other important topics: human rights, the national question, the protection of the Ukrainian language, literature, religion and the Jewish question.

Human rights issues include all documents directly requesting protection ("Open letter to the editorial board of Literary Ukraine in defense of V. Chornovil" (1968), "Appeal of 3 Ukrainian political prisoners to the

21 Універсальна десяткова класифікація. Національна бібліотека Украӥни ім. В. I. Вернадського. URL: http://www.nbuv.gov.ua/texts/libdoc/udc.htm 
Commission on Human Rights at UN (1969)), or providing information on political prisoners, political trials ("Arrests and trials in Ivano-Frankivsk and other cities of Ukraine in 1967-1968") (1968), Judgment of former UPA soldier Myron Simchyk (1970), or relating to the materials of the UGG "Memorandum № 2 of the Ukrainian Public Group for Promoting the Implementation of the Helsinki Accords" (1977) and others.

Most of the documents are human rights issues, this group includes $70,87 \%$ of the total. This concentration of Ukrainian samizdat activists on the human rights situation is not accidental, as the repressive actions of the authorities were aimed at punishing those who disagree with official policy, to destroy them physically, which was quite often possible. In this situation, dissidents were forced to appeal to any instance, seek help and disseminate information about violations of civil rights in the USSR and abroad.

Human rights texts have been regularly distributed in Ukraine since 1963. ("Explanatory note to the Union of Soviet Writers of Ukraine on the evening in memory of Lesya Ukrainka in Kyiv on August 17, 1963" by I. Dzyuba), but at this time there are not many of them. Immediately after the arrests in 1965, in 1966 their number increased to 27 titles ("Record of the trial of teacher Mykhailo Ozerny", "Lviv court verdict in the case of Ivan Gel and Yaroslava Menkush", "List of 58 Ukrainians who were administratively persecuted for their convictions" etc.).

In 1970, an increase in the number of documents on human rights issues was recorded. There were 50 titles a year ("Another massacre of V. Moroz is being prepared", "Massacre of "Gomon", "Petition to the USSR Prosecutor's Office from S. Karavansky, convicted by the Vladimir Regional Court 23.04.70 under Article 70 Part 2 for a total of up to 10 years of special regime correctional labor camps", etc.). The decline in the distribution of documents is recorded from 1971 (19 titles) to 1973 (six titles), but in 1974 we recorded 19 titles of documents and further their number increases. Each year, on average, about 16 titles of human rights documents were distributed during the study period.

We recorded significantly fewer documents on the national issue - only $10,84 \%$ of the total (70 titles). The regular distribution of such documents has been recorded since 1964, when the following publications appeared: "About the trial over Pogruzhalsky" by Ye. Sverstyuk, anonymous "Appeal to all communists of the people's democratic and capitalist countries, to the leaders of the communist and workers' parties of the world" and the first issue of magazine of the Ukrainian National Front "Volya i Bat'kivshchyna.

In the period from 1964 to 1965 , the number of titles devoted to the national question (17 titles) was dominated by human rights documents (8 titles), which indicates an increased public interest in this topic, 
which was restrained only by repression. Despite pressure from the authorities, documents on this subject were distributed from 1966 to 1969, but their number did not exceed three to five titles a year. An increase in the number of documents devoted to the national question was recorded in 1970. This happened due to the activity of V. Moroz, who distributes his political essays "Chronicle of Resistance", "Among the Snows", which diverged in Russian and Ukrainian.

This year there are three issues of "Ukrainian Herald" and an article by V. Chornovil "What and how B. Stenchuk defends (66 questions and comments by "internationalists", an article by N. Plahotniuc "Truth is behind us", an anonymous article "The same process of "internationalism" and others. In the future, the number of names of such documents did not increase. In the period from 1971 to 1978 no more than three units a year appeared. In the future, these documents were not recorded until 1987.

We investigate all Ukrainian literary works distributed by the Ukrainian samizdat, as well as articles devoted to fiction. In total, $10,03 \%$ of the total number of such documents (63 titles) was recorded. Interest in documents on this topic has been recorded since 1960, when I. Dziuba's article "Poetic and Ordinary Life" was distributed. Later, in 1962, another article by the same author "Our first mind is Grigory Skovoroda" was distributed. After V. Symonenko's death, in December 1963, his "Diary" was distributed, and the speeches of Ye. Sverstyuk and I. Svitlychny at the evening of remembrance dedicated to the poet were also published.

In 1965 there was an increase in the number of common titles of documents to 12, among these documents: "Literature and pseudo-literature in Ukraine" by M. Masyutko, "Through the eyes of a prominent publicist (Taras Shevchenko in the assessment of Borys Hrinchenko)" by V. Chornovil, poetry collections by I. Kalynets and etc. In the following years, interest in literary subjects remained at the level of two to five titles per year until 1979. In the future, only single documents on this topic are recorded.

Religious topics occupy a relatively small percentage - 3,56. The Ukrainian community of Evangelical Baptists was the most active in defending their rights. The Decisions of the Supreme Court of the Ukrainian SSR have been preserved, in which activists of this community were condemned for distributing religious literature and other materials. Thus, V. Kyrylko, a resident of Kyiv, was sentenced in 1967 to three years in prison for distributing the "Brotherly Leaflet", "Appeal", etc., which he reproduced with a homemade glass recorder ${ }^{22}$. A year later, another member

${ }^{22}$ ЦДАВО України. Ф., 24, оп.: 16, од. зб.: 975, спр. № 725. Арк 67. 
of the Evangelical Baptist community, V. Lavrinek, was convicted of copying and distributing religious literature in Kyiv and a homemade glass recorder was confiscated from his home ${ }^{23}$. In 1969, Lviv residents M. Datsko, V. Petlyokha and G. Lukyanchuk were convicted for such activities $^{24}$.

Much of the information was spread through the efforts of one of the community's leaders, G. Vince, and his family: "An open letter to Brezhnev from Evangelical Baptist youth demanding the rehabilitation of nine Baptists" (1969), "Appeal of a group of believers to the World Council of Churches (Odessa) with a complaint about the illegal interference of the secular authorities in the affairs of spiritual administration", "Short record of the trial over G. Vince in Kyiv" and others.

Representatives of the Greek Catholic Church were also persecuted. In 1969, V. Velychkovsky was sentenced to three years in prison for "systematically disseminating oral and written false fabrications in the Soviet state and social order, and for writing the book "The History of the Miraculous Icon of God mothers of constant help"25. A total of 22 titles of religious documents were recorded, which is $3.56 \%$ of the total. Documents on this topic were regularly distributed from 1963 to 1979.

The topic of protection of the Ukrainian language was directly raised in 1964-1965 along with the national question. During this period, V. Lobko's letters to M. Rylsky were distributed, in which the author asked the writer to more actively defend the Ukrainian language and to use it not only in literature $^{26}$. In another appeal to the Verkhovna Rada of the Ukrainian SSR, the Presidium of the Central Committee of the Communist Party of Ukraine, the Council of Ministers of the Ukrainian SSR entitled "Our Proposals" V. Lobko and several other people propose to expand the use of the Ukrainian language. Also in 1964, an anonymous leaflet "Comrades, parents of schoolchildren!" was distributed. It proposed to introduce teaching in the Ukrainian language in the schools of the Ukrainian SSR. S. Karavansky's "Petition to the Prosecutor of the Ukrainian SSR about Serious Mistakes and the Proclamation of Russification by the Minister of Higher and Secondary Education of the Ukrainian SSR Yu. M. Dadenkov" was quite resonant.

In total, language issues account for $1,94 \%$ of the total number or 12 recorded names. A characteristic feature of this thematic group is that the documents were distributed only for two years in the indicated period, later only individual documents were recorded: in 1969, "On the situation of the

\footnotetext{
${ }^{23}$ ЦДАВО України. Ф. 24, оп.: 16, од. зб.: 1012, спр. № 05-526К. Арк. 68.

${ }^{24}$ ЦДАВО України. Ф. 24, оп.: 16, од. зб.: 1068, спр. № 0547. Арк. 69.

25 Ibid.

${ }^{26}$ Музей-архів українського самвидаву “Смолоскип”. СДС. Т. 18.
} 
Ukrainian language in the Crimean Pedagogical Institute" by V. Skrypka, "Letter of Reflections on the Question "About the deep crisis in the use of the Ukrainian language in the publication of scientific research and scientific works of the USSR Academy of Sciences" by V. Kumpanenko, "On the article by B. Antonenko-Davidovich "The Letter They Long For" by K. Kozub and in 1974, "Reflections on the Ukrainian language and culture in the Donetsk region" by O. Tykhy.

The Jewish national movement in the USSR intensified during the Stalinist thaw, during which time a small number of Jews were allowed to emigrate to Israel: in $1954-53$ people, in $1955-106$, in $1956-753$. The centers of these processes were Moscow, Leningrad, the Baltics, however, these processes took place in Ukraine. There were two Zionist groups in Odessa in the late 1960s: one under the leadership of Abram Shifrin, the other was headed by Moshe Melher. In Kyiv, B. Kochubievsky wrote and distributed a self-published article "Why am I a Zionist?", "For which I ended up in the dock in 1968"27. Information about him was also disseminated by the Ukrainian samizdat, "Summary of the court hearing in the case of Borys Kochubievsky", a letter to L. I. Brezhnev and P. Yu. Shelest with a demand to release B. Kochubievsky to Israel. In general, among the documents distributed, the central place was occupied by requests to leave the USSR for Israel, for example, "Please release me from the USSR (request sent to the Ministry of Internal Affairs of the USSR)" by Yu. Dziuba. Documents on the Jewish question occupy $1,94 \%$ or 12 titles among those recorded.

The period of active dissemination of these documents dates back to 1968-1974, which coincides with the period of the national rise of the Jews after the victory of Israel in the Six Day War of 1967. After 1974, such documents were not recorded, this is due to a change in the policy of the USSR leadership in this matter. Responding to increased support for the struggle of Soviet Jews in the West, counting on the weakening of the Zionist movement in the USSR after the departure of the "rebels", the Soviet leadership sharply increased the number of exit permits. In 1971, 12900 Jews left the country, in 1972 - already $31900^{28}$.

\section{CONCLUSIONS}

In this paper, for the first time, it is proposed to consider the texts of the Ukrainian samizdat as an underground publishing product; its main types are identified and on their basis a typological analysis is carried out. It was revealed that for the purpose (functional) purpose, the majority are

27 Бейзер Михаэль Еврейское агентство для Израиля. URL: http://www.jewishagency.org/JewishAgency/Russian/Education/Jewish+History/40/hhis.htm.

${ }^{28}$ Ibid. 
socio-political documents, the total share of which is $87,22 \%$, literary works are only $6,63 \%$ of the total, official $-4,21 \%$, reference $-1,29 \%$, scientific $0,65 \%$. By material design the bulk of the texts, about $99 \%$, are sheet- fed, printed on a conventional typewriter. Only one percent are photocopies. It was also established that the self-published works replicated on the Era machine, as well as on self-made glass-recorder, however, we have not recorded similar ones.

By volume 53,56\% of the identified texts of Ukrainian samizdat are postcards. Brochures are only $29,13 \%$, the smallest number of books recorded, only $5,66 \%$. We note that it was not possible to establish the amount of about $11,65 \%$ of the total number of non-periodic samizdat documents. Monographs account for 93,68\%, and collections are 6,32\%. It was established that only $1,94 \%$ of the total number of texts can be considered serial, $98,06 \%$ are non-periodicals. The majority $(94,98 \%)$ are original texts, translated only $5,02 \%$.

Four types of documents belonging to the author are analyzed: proprietary, anonymous, collective and departmental. Own, or those distributed with a signature, are the majority of recorded documents $(69,74 \%)$. Less anonymous texts were found-16,02\%, collective are $11,33 \%$. Departmental texts are only $2,91 \%$ of the total. The majority of identified documents are written in Ukrainian, their share is $74 \%$, in Russian $-26 \%$ of all documents.

\section{SUMMARY}

In this work, the author explores the non-periodic Ukrainian samizdat, in particular, finds out its thematic and typological characteristics. He concludes that in the study period, texts of human rights topics dominated, the amount of which is about $70,87 \%$. Texts on the national question take the second place in terms of prevalence $-10,84 \%$. Literary themes were recorded slightly less, only $10,03 \%$. Religious topics include $3,56 \%$ of recorded texts, and only $1,94 \%$ of all texts are devoted to the protection of the Ukrainian language and the Jewish national question.

\section{REFERENCES}

1. Бейзер Михаэль Еврейское агентство для Израиля. URL: http://www.jewishagency.org/JewishAgency/Russian/Education/Jewish+His tory $/ 40 /$ hhis.htm.

2. Бердиховська Б., Гнатюк О. Бунт покоління: Розмови з українськими інтелектуалами. К. : Дух і літера, 2004. 332 с.

3. Геврич Я. Музей дисидентського руху. URL: http:// archive.khpg.org/index.php?id=1257671444. 
4. Доброокий: Спогади про Івана Світличного. Упоряд. Леонід i Надія Світлична. К. : ЧАС, 1998. 572 с.

5. ДСТУ 3017-95. Видання. Основні види. Терміни та визначення. К. : Держстандарт України, 1995. 47 с.

6. Касьянов Г. Незгодні: українська інтелігенція в Русі Опору 1960-1980-х років. К. : Либідь, 1995. 224 с.

7. Кіпіані В. Самвидав як проба протистояти цензурі. Дивен Світ. URL: http://dyvensvit.org/suspilstvo/178-suspilstvo-statti/3111-vahtangkipiani-samvydav-jak-sproba-protystojaty-cenzuri.

8. Музей-архів українського самвидаву “Смолоскип”, п. № 18.

9. Музей-архів українського самвидаву “Смолоскип”. СДС. Т. 18.

10. Обертас О. Український самвидав: літературна критика та публіцистика (1960-і - початок 1970-х років). К. : Смолоскип, 2010. $300 \mathrm{c}$.

11. Спанатій О. С. Канали перевезення самвидаву на Захід у 1960 1980-х pp. Наукові записки Інституту журналістики: науковий збірник. К., 2009. Т. 35. Квітень-червень. С. 40-42.

12. Тимошик М. С. Книга для автора, редактора, видавця : практ. посіб. - 2 вид., стер. К. : Наша культура і наука, 2006. 560 с.

13. Українські юристи під судом КГБ. Мюнхен : Сучасність, 1969. $107 \mathrm{c}$.

14. Універсальна десяткова класифікація. Національна бібліотека Украӥни ім. В. I. Вернадського. URL: http://www.nbuv.gov.ua/texts/ libdoc/udc.htm.

15. ЦДАВО України. Ф. 24, оп.: 16, од. зб.: 1012, спр. № 05-526К. Арк. 68.

16. ЦДАВО України. Ф. 24, оп.: 16, од. зб.: 1068, спр. № 0547. Арк. 69.

17. ЦДАВО України. Ф. 24, оп.: 16, од. зб.: 1113, спр. № 05-205. Арк 70.

18. ЦДАВО України. Ф., 24, оп.: 16, од. зб.: 975, спр. № 725 . Арк 67.

19. Чорновіл В. Твори: у 10 т. К. : Смолоскип, 2006. Т. 3 : Український вісник. Випуски I-VI. 976 с.

\section{Information about the author:} Spanatiy O.S.,

$\mathrm{PhD}$ in Social Communications, Department of Social Studies and Humanities, Admiral Makarov National University of Shipbuilding 9, Heroes of Ukraine Avenue, Mykolaiv, 54025, Ukraine

ORCID ID: orcid.org/0000-0003-1939-3900 